\title{
On the Origin of Indonesian Cattle
}

\author{
Kusdiantoro Mohamad ${ }^{1,2}$, Mia Olsson ${ }^{3,4}$, Helena T. A. van Tol $^{2}$, Sofia Mikko ${ }^{3}$, Bart H. Vlamings ${ }^{2}$, \\ Göran Andersson ${ }^{3}$, Heriberto Rodríguez-Martínez ${ }^{5}$, Bambang Purwantara', Robert W. Paling ${ }^{2}$, \\ Ben Colenbrander ${ }^{2}$, Johannes A. Lenstra ${ }^{2 *}$
}

1 Faculty of Veterinary Medicine, Bogor Agricultural University, Bogor, Indonesia, 2 Faculty of Veterinary Medicine, Utrecht University, Utrecht, The Netherlands, 3 Department of Animal Breeding and Genetics, Swedish University of Agricultural Sciences (SLU), Uppsala, Sweden, 4 Department of Microbiology and Medical Biochemistry, Uppsala University, Uppsala, Sweden, 5 Division of Reproduction, Swedish University of Agricultural Sciences (SLU), Uppsala, Sweden

\begin{abstract}
Background: Two bovine species contribute to the Indonesian livestock, zebu (Bos indicus) and banteng (Bos javanicus), respectively. Although male hybrid offspring of these species is not fertile, Indonesian cattle breeds are supposed to be of mixed species origin. However, this has not been documented and is so far only supported by preliminary molecular analysis.

Methods and Findings: Analysis of mitochondrial, Y-chromosomal and microsatellite DNA showed a banteng introgression of $10-16 \%$ in Indonesian zebu breeds. East-Javanese Madura and Galekan cattle have higher levels of autosomal banteng introgression (20-30\%) and combine a zebu paternal lineage with a predominant (Madura) or even complete (Galekan) maternal banteng origin. Two Madura bulls carried taurine Y-chromosomal haplotypes, presumably of French Limousin origin. In contrast, we did not find evidence for zebu introgression in five populations of the Bali cattle, a domestic form of the banteng.
\end{abstract}

Conclusions: Because of their unique species composition Indonesian cattle represent a valuable genetic resource, which potentially may also be exploited in other tropical regions.

Citation: Mohamad K, Olsson M, van Tol HTA, Mikko S, Vlamings BH, et al. (2009) On the Origin of Indonesian Cattle. PLoS ONE 4(5): e5490. doi:10.1371/ journal.pone.0005490

Editor: Robert DeSalle, American Museum of Natural History, United States of America

Received February 2, 2009; Accepted April 14, 2009; Published May 13, 2009

Copyright: (C) 2009 Mohamad et al. This is an open-access article distributed under the terms of the Creative Commons Attribution License, which permits unrestricted use, distribution, and reproduction in any medium, provided the original author and source are credited.

Funding: Asia Link Project Reproductive biotechnology: modern technology to improve livestock production under traditional Asian conditions, European Union. Swedish Research Council Grant 348-2005-5992: Conservation biology of Banteng and Bali cattle in Indonesia. Strengthening of research capabilities in cryobanking and breeding soundness evaluation of Bali bulls for artificial insemination purposes. The funders had no role in study design, data collection and analysis, decision to publish, or preparation of the manuscript.

Competing Interests: The authors have declared that no competing interests exist.

* E-mail: J.A. Lenstra@uu.nl

\section{Introduction}

Several bovine species have contributed worldwide to cattle livestock [1]. Most domestic cattle belong to the species Bos taurus or Bos indicus (zebu), which both descend from the wild aurochs (Bos primigenius). Domestic yak (Bos grunniens) is kept in and around Tibet, the gayal (Bos frontalis) of Eastern India is derived from the gaur (Bos gaurus), while the Indonesian Bali cattle is a domestic form of the banteng (Bos javanicus). Despite their obvious role as livestock during our cultural development, the history of domestic cattle has been poorly documented. For the past 15 years, DNA analysis has allowed a phylogenetic reconstruction of the earliest events during domestication [2,3]. For instance, analysis of mitochondrial DNA established a taurine maternal origin of zebu breeds outside Asia [4,5]. Indonesian cattle breeds are supposed to be derived from zebu as well as from banteng [6].

Domestic Bali cattle is kept on Bali, East Java and on isolated regions on Sumatera and Sulawesi. It offers the advantage of a high resistance against most diseases, a remarkable ability to grow on low-quality fodder and a high fertility [7]. On the other hand, Bali cattle cannot be reared very well together with sheep because of their susceptibility to malignant catarrhal, while juvenile mortality is relatively high. A deer-like temperament makes them most suitable for intensive village-based management for plowing rice paddy fields [8], but their hoofs are too soft for draught on paved roads. Meat from young animals has a reputation of being exceptionally tender.

Crosses of banteng and zebu produce viable offspring, but male hybrids are not fertile [1]. However, the mixed banteng zebu species origin is not supported by breeding records, while only sporadic molecular data are available $[9,10,11,12,13,14]$. Via an analysis of the maternal, paternal and autosomal species origin of five zebu breeds and five populations of Bali cattle, we show here that the species composition of Indonesian zebu breeds is unique and varies from mainly zebu to completely banteng. This information is of direct relevance for the genetic management and conservation of Indonesian cattle breeds.

\section{Materials and Methods}

\section{Samples and DNA isolation}

All animals were handled by veterinarians from the Faculty of Veterinary Medicine, Bogor Agricultural University in strict accordance with good animal practice following the guidelines of the Institutional Animal Care and Use Committee of Utrecht 
University. Blood and skin tissue samples from Bali cattle and banteng and blood samples from zebu breeds were collected on different locations (table 1). Blood and skin tissue samples from 8 bantengs were obtained from Ragunan Zoo, Jakarta. DNA was isolated by using standard SDS/proteinase $\mathrm{K}$ extraction [15] or the Qiagen blood and tissue extraction kit (Qiagen, Valencia, USA).

\section{PCR-RLFP and sequencing}

PCR-RLFP on a mitochondrial cytochrome $b$ gene segment was carried out as described previously [16] with separate digestions by $X b a \mathrm{I}$ and $T a q \mathrm{I}$, indicating a zebu and banteng origin, respectively. In all cases, the separate digestions of mitochondrial DNA agreed and ruled out mistypings by genetic polymorphisms or failure of the digestions. PCR-RFLP of a Y-chromosomal SRY gene segment, in which a $B f a \mathrm{I}$ site indicates a banteng origin (table 2), was performed as described [16]. The absence of the $B f a I$ site in undigested samples was confirmed by sequencing the same $S R Y$ fragment, which also indicated second banteng-specific mutation and differentiated between zebu and taurine origin [17]. For two samples a taurine origin was confirmed by sequencing intron 10 from the $Z F Y$ gene segment $[17,18]$. For these samples, an indel in the same intron [18] as well as genotyping by K-Bioscience (Hoddesdon, UK) of single-nucleotide polymorphisms (SNPs) in exon 11 of $Z F Y$ and in UTY [18,19] differentiated between the taurine Y1 and Y2 haplotypes. Table 2 summarizes the Ychromosomal species variation and haplotype variation.

\section{Microsatellite genotyping}

Microsatellite analysis of the loci INRA63, INRA5, ETH225, ILSTS5, HEL1, INRA35, ETH152, ETH10, CSSM66, ETH3, BM2113, BM1824, HEL13, BM1818, ILSTS6 and CSRM60 was carried out using $10 \mathrm{ng}$ of genomic DNA, $2 \mu \mathrm{M}$ of M13 tailed
Table 2. Y-chromomal sequence variation diagnostic for indicine and $Y 1$ and $Y 2$ taurine haplotypes.

\begin{tabular}{|c|c|c|c|c|c|c|c|}
\hline \multirow{3}{*}{$\begin{array}{l}\text { Gene } \\
\begin{array}{l}\text { Genbank } \\
\text { entry }\end{array} \\
\text { Position }\end{array}$} & \multicolumn{3}{|l|}{$S R Y$} & \multicolumn{3}{|l|}{$Z F Y$} & \multirow{3}{*}{$\begin{array}{l}\text { UTY } \\
\text { AY936543 } \\
423\end{array}$} \\
\hline & \multicolumn{3}{|c|}{ DQ336526 } & \multicolumn{2}{|c|}{ DQ336536 } & \multirow{2}{*}{$\frac{\text { DQ336546 }}{71}$} & \\
\hline & $2059^{*}$ & 2100 & 2144 & 614 & $697-698$ & & \\
\hline Taurine Y1 & A & C & $\mathrm{T}$ & $C$ & deletion & G & G \\
\hline Taurine Y2 & A & $\mathrm{C}$ & $\mathrm{T}$ & $\mathrm{C}$ & TG & $\mathrm{T}$ & $\mathrm{T}$ \\
\hline Zebu & A & $\mathrm{T}$ & $\mathrm{T}$ & $\mathrm{T}$ & TG & $\mathrm{T}$ & $\mathrm{T}$ \\
\hline Banteng & G & C & C & $\mathrm{T}$ & TG & $\mathrm{T}$ & $\mathrm{T}$ \\
\hline
\end{tabular}

*Corresponding to the $\mathrm{Bfal}$ site in banteng.

Database entries and the numbering refer to sequences from taurine cattle. doi:10.1371/journal.pone.0005490.t002

forward primer, $10 \mu \mathrm{M}$ of reverse primer, $10 \mu \mathrm{M}$ of $\mathrm{M} 13$ oligonucleotide coupled to a fluorescent dye, Taq DNA polymerase and a standard PCR protocol. Fragments were separated on an ABI 3100 apparatus (Applied Biosystems, Foster City, CA). Allele size lengths have been standardized via comparison with a common reference sample. Data from Indian zebu breeds are from ref. [20].

\section{Data analysis}

Checking of microsatellite data and calculation of expected heterozygosities was performed using the Excel-based microsatellite toolkit (http://animalgenomics.ucd.ie/sdepark/ms-toolkit/). Nei standard genetic distances were calculated using the program Microsat (http://hpgl.stanford.edu/projects/microsat/). NeighborNet graphs were constructed by the program Splitstree

Table 1. Genetic constitution of Indonesian and Indian cattle breeds.

\begin{tabular}{|c|c|c|c|c|c|c|c|c|}
\hline \multirow[t]{2}{*}{ Breed/population } & \multicolumn{2}{|l|}{ sampling site } & \multicolumn{2}{|c|}{ samples } & \multicolumn{4}{|l|}{ microsatellites } \\
\hline & country/isle & location & males & females & genotypings & $H_{\text {exp }}$ & $H_{\text {obs }}$ & $\%$ banteng* \\
\hline Ongole & India & & & & 32 & 0.64 & 0.67 & \\
\hline Nellore & Brasil & & & & 27 & 0.63 & 0.62 & \\
\hline Tharparkar & India & & & & 35 & 0.6 & 0.63 & \\
\hline Red Sindi & India & & & & 35 & 0.7 & 0.69 & \\
\hline Sahiwal & India & & & & 10 & 0.58 & 0.56 & \\
\hline Desi & India & & & & 24 & 0.65 & 0.66 & \\
\hline Hariana & India & & & & 10 & 0.68 & 0.67 & \\
\hline Aceh & North Sumatera & Langsa & 8 & 3 & 11 & 0.68 & 0.68 & 10.8 \\
\hline Pesisir & West Sumatera & Painan & 17 & 8 & 24 & 0.65 & 0.6 & 15.7 \\
\hline Filial Ongole & South Sumatera & Palembang & & 5 & 5 & 0.78 & 0.72 & 16.3 \\
\hline Galekan & East Java & Trenggalek & 36 & 10 & 16 & 0.73 & 0.69 & 22.0 \\
\hline Madura & Madura & Bangkalan & 18 & 23 & 28 & 0.75 & 0.65 & 31.3 \\
\hline Bali cattle & West Sumatera & Sijunjung & 15 & 23 & 20 & 0.67 & 0.59 & \\
\hline Bali cattle & South Sumatera & Palembang & 24 & 9 & 31 & 0.62 & 0.58 & \\
\hline Bali cattle & South-West Sumatera & Bengkulu & 5 & 3 & 5 & 0.7 & 0.58 & \\
\hline Bali cattle & Sulawesi & Kendari, Kanowe Selatan & 9 & 21 & 29 & 0.64 & 0.56 & \\
\hline Bali cattle & Bali & Denpasar, Tabanan & 25 & 33 & 31 & 0.61 & 0.58 & \\
\hline Banteng & Java & Ragunan zoo, Jakarta & 6 & 2 & 8 & 0.37 & 0.39 & \\
\hline
\end{tabular}

*from the q value (Pritchard et al., 2000) after analysis with Indian zebus and Bali cattle as predefined clusters.

doi:10.1371/journal.pone.0005490.t001 
(http://www.splitstree.org/, [21]). Model-based clustering was carried out using the program Structure (http://pritch.bsd. uchicago.edu/software.html , [22], assuming admixture and correlated allele frequencies. Reproducible clustering was obtained after 30,000 burnin steps and 40,000 simulations. Clusters were either inferred or predefined as Indian zebu and Bali cattle, respectively. Results were displayed by the program Distruct (http://rosenberglab.bioinformatics.med.umich.edu/distruct.html, [23]).

\section{Results}

As indicated by specific PCR-RFLP assays and sequencing, the sampled Aceh and Pesisir zebus have zebu mitochondrial DNA, while maternal lineages from both species are represented in Filial Ongole cattle (figures 1 and 2). In two earlier studies, banteng mtDNA has been found in 20 out of 26 [9] or six our of seven [10] Filial Ongole animals. We found banteng mtDNA also in 56\% and 94\% of the East-Javanese Madura and Galekan zebu samples, respectively. However, the maternal origin of Bali cattle from five different locations on three isles is almost exclusively banteng with a zebu origin found for only 1 out of 125 sampled animals. This is in contrast to the mixed maternal origin of Bali cattle from Malaysia [13], but agrees with the results obtained for a feral population of Bali cattle [24].

Interestingly, Y-chromosomal typing as a probe of the paternal lineage does not completely parallel the mtDNA results (figure 1 and 2). All zebu bulls carry exclusively zebu Y-chromosomes. Only female Filial Ongole animals were sampled, but in another study [10] seven bulls from this breed were found to carry zebu Ychromosomes. Zebu Y-chromosomes were also found in the EastJavanese Galekan and Madura breeds. However, for two Madura bulls the sequence of the $Z F Y$ and SRY gene segments (table 2) indicate a taurine origin, possibly resulting of experimental crosses with Danish Red and French Limousin bulls [8]. These two European breeds carry different Y-chromosomal haplotypes (Y1 and Y2, respectively, [19]). Different diagnostic SNPs (table 2) revealed that both Madura bulls with taurine Y-chromosomes carried the Y2 haplotype, compatible with a Limousin origin. The parental origin of Madura cattle may also depend on the sampling site, because we previously found banteng Y-chromosomes in two Madura bulls from a breeding station in Malang on Java [14].
With one exception in South Sumatera, all Bali cattle in our study descend from banteng bulls.

For estimation of the autosomal species composition, we genotyped 16 microsatellite markers from the panel of 30 microsatellites recommended by the FAO for diversity studies (http://lprdad.fao.org/cgi-bin/getblob.cgi?sid = -1,50006220) and compared the data with genotypes for the same markers from seven Indian zebu populations [20]. As indicated by the expected heterozygosity, genetic diversity of Indonesian cattle compares to that of Indian (table 1). In Bali cattle observed heterozygosity is clearly lower than the expected values, presumably because of inbreeding within local populations. However, clearly higher heterozygosity values were observed for the Indonesian Ongole, Madura and Galekan, while the lowest value found for eight wild bantengs probably indicates inbreeding in a zoo population.

Allele distributions (not shown) of Indonesian and Indian breeds also matched well. However, for several markers additional alleles also present in Bali cattle were observed. Quantitative species components were estimated by two different methods (see [25]). First, Nei genetic distances were visualized in a Neighbor Network (figure 3), Indonesian Aceh, Pesisir and Filial Ongole are close to the Indian zebu breeds, but are intermediate between Indian zebu and Bali cattle. Interestingly, Madura and Galekan cattle, several of which carry banteng mitochondria, are more distant from the Indian zebu and closer to Bali cattle. The different Bali cattle populations appear to be identical. Adding genetic distances to the captive banteng population links this population to Bali cattle with a distance that probably corresponds to their inbreeding (not shown).

Second, unsupervised model-based clustering, i.e., without prior information on ancestral clusters, [22] identified a zebu and a Bali cattle cluster (figure 2). Assuming that Indian zebu and Bali cattle are the ancestral populations we then carried out supervised clustering in order to estimate the levels of introgression via the individual membership coefficients (figure 2, table 1). For Aceh, Pesisir and Filial Ongole banteng introgression is in the range of $11-16 \%$, but this is clearly higher for Galekan (22\%) and Madura cattle (31\%).

\section{Discussion}

Domestication of banteng probably took place around 3500 years BC [6,8]. Bali cattle is currently the main representative of the domestic banteng, and it is kept on several Indonesian Isles. A

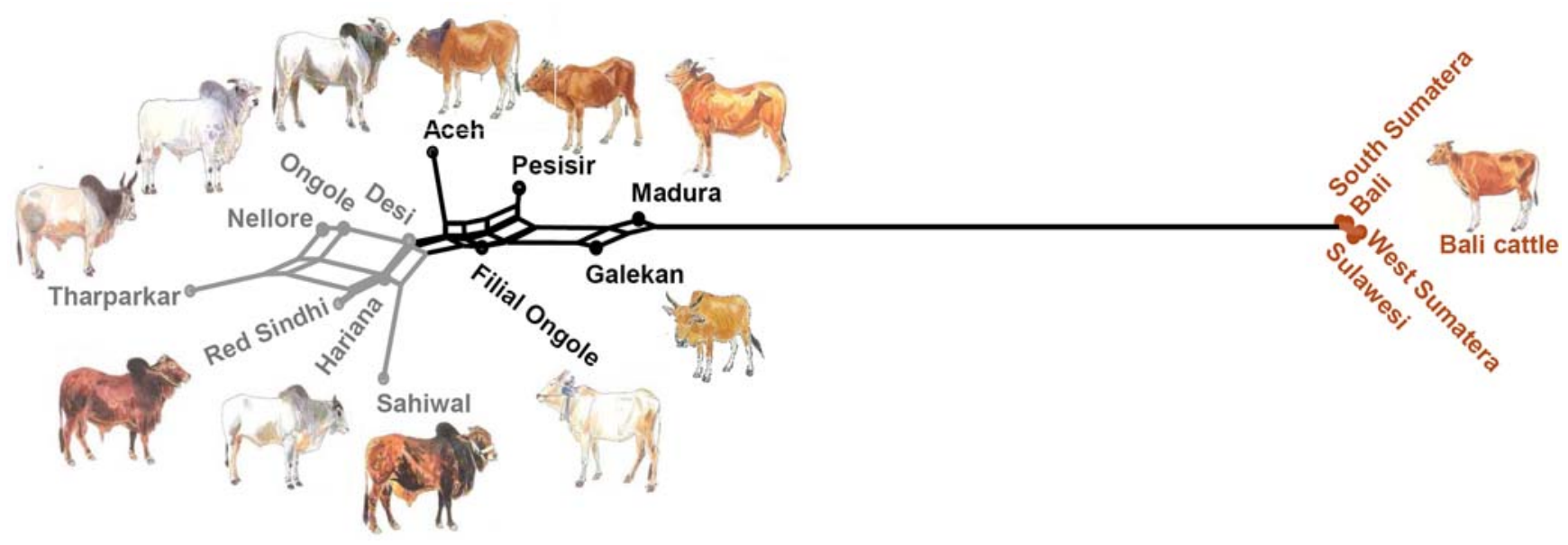

Figure 1. Locations of sampling and genetic constitution of Indonesian cattle populations. The species origin of the $Y$-chromosomes ( $\mathrm{Y}$ ), mitochondrial DNA $(\mathrm{mt})$ and autosomal microsatellite alleles $(\mu \mathrm{st})$ is represented by brown and gray shading of the indicated circle segments. doi:10.1371/journal.pone.0005490.g001 


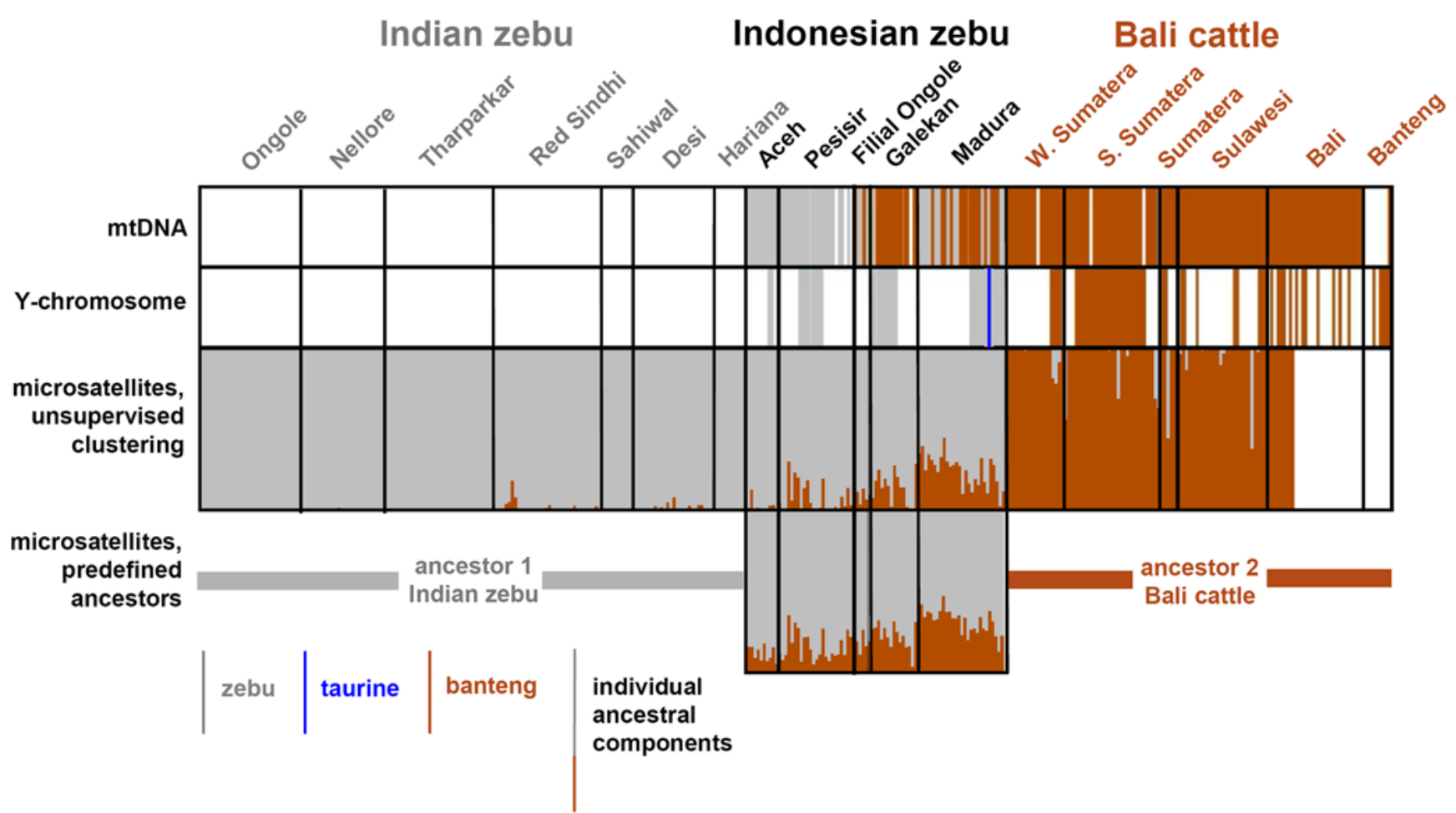

Figure 2. Genomic components of Indonesian cattle animals. Animals are represented as vertical lines, the color of which indicates zebu of banteng mitochondrial DNA (top panel), zebu, taurine or banteng Y-chromosomal DNA (second panel, only for males), the proportion of the individual genomes derived from the two clusters identified by unsupervised model-based clustering (third panel) or from the proportions derived from two predefined clusters (Indian zebu and Bali cattle, bottom panel). Each animal is plotted in the respective panels at the same position. A white line indicates absence of data.

doi:10.1371/journal.pone.0005490.g002

cattle population in Pandaan on East Java is also supposed to originate from banteng (T. Susilawati, Malang, pers. comm.). There is no reliable dating of the entry of the more common cattle species, which in Indonesia was very likely predominantly of zebu origin $([26,27])$. Singalese immigrants may 1500 years ago have brought Indian cattle ([8]). Statues of a humped bull on Javanese Hindu temples evidence the presence of zebus in the $10^{\text {th }}$ century. Photographs of original Javanese cattle from the beginning of the $20^{\text {th }}$ century $([28,29])$ also show humped cattle and resembled Madura cattle. However, starting by the end of the $19^{\text {th }}$ century, imported Ongole zebu were more and more used for breeding on Java and other Indonesian isles, but not on the isles of Madura and Bali $[6,8,28]$.

The predominance of zebu mitochondria in the Indonesian zebu breeds shows that not only zebu bulls but also zebu cows were imported. This is in contrast to the zebu populations in Africa and America, which emerged by systematic crossing of imported zebu bulls with taurine cattle [4,5]. Banteng mitochondria in Indonesian Ongole populations as well as the autosomal microsatellite analysis indicate crossbreeding of zebu and local cattle with a banteng maternal origin.

The Eastern Java Galekan cattle are supposed to descend from original Java cattle (T. Susilawati, personal communication). DNA analysis indicates that it descends from banteng cows and zebu bulls. Madura has long tradition of well managed cattle husbandry $[28,30,31]$. The Madura breed predates the import of Ongole bulls and Madura bulls were used for crossing on East Java before the import of Ongole bulls [28]. DNA analysis of Madura cattle shows a combination of a zebu paternal lineage with a mixed zebu-banteng maternal origin. Experiments of upgrading the local cattle with Danish Red and Limousin taurine bulls, which have similar coat colors [8] were not pursued, but apparently left taurine Y-chromosomes in the Madura population. Although indiscriminate cross-breeding with exotic breeds is a major threat to the conservation of genetic resources, it is also evident that introgression of foreign material at such a low level in this case did not affect the identity of the breed.

Our data further indicate that Bali cattle on different locations in Indonesia has been kept separate from zebu, this in contrast to mixed zebu-banteng Bali cattle populations from Malaysia [13].

Evidently, the history and breeding of Indonesian cattle has resulted in a unique genetic resource that combines the general tolerance of zebu to tropical and dry climates with the adaptation of domestic banteng to Indonesian conditions and husbandry. Information about the history and species composition as reported here appears most essential for strategic choices regarding breed management and conservation. Furthermore, the adaptation of Indonesian cattle to different modes of management under tropical conditions may very well be exploited outside Indonesia, especially if the high-temperature zones expand because of current global climate trends [32].

\section{Acknowledgments}

We thank the farmers, breeding organizations and veterinarians for their willingness to supply samples of their cattle and for their help and advice. We thank Dr. D.G. Bradley (Dublin) for making available the genotypes from Indian zebus. We thank Mrs. M. Felius for permission to use published animal pictures and for drawing new pictures of Indonesian cattle from photographs gracefully provided by Dr. R.R. Noor, Mr. M.A.N. Abdullah (Bogor) and Dr. T. Susilawati (Malang). 


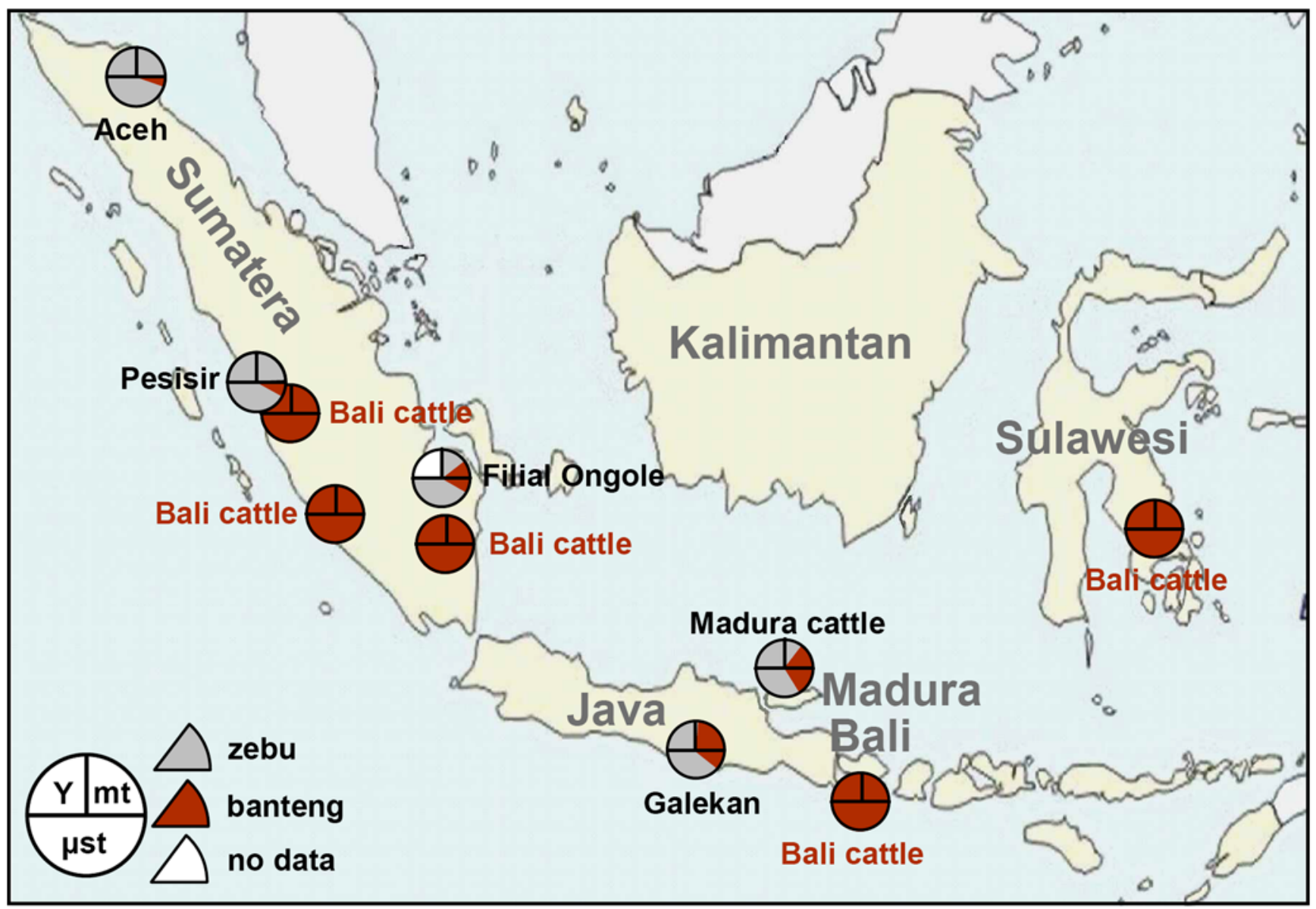

Figure 3. NeighborNet graph of genetic distances of Indonesian cattle populations. The animal pictures are from [8] or were drawn from photographs.

doi:10.1371/journal.pone.0005490.g003

\section{Author Contributions}

Conceived and designed the experiments: KM GA HRM BP RWP BC JAL. Performed the experiments: KM MO HTAVT SM BHV. Analyzed

\section{References}

1. Lenstra JA, Bradley DG (1999) Systematics and phylogeny of cattle. In: Ruvinsky RFA, ed. The genetics of cattle. Wallingford: CAB Int. pp 1-14.

2. Bruford MW, Bradley DG, Luikart G (2003) DNA markers reveal the complexity of livestock domestication. Nat Rev Genet 4: 900-910.

3. Hall SJG (2004) Livestock Biodiversity: Genetic resources for the farming of the future Blackwell Science.

4. Bradley DG, MacHugh DE, Cunningham P, Loftus RT (1996) Mitochondrial diversity and the origins of African and European cattle. Proc Natl Acad Sci U S A 93: 5131-5135.

5. Loftus RT, MacHugh DE, Ngere LO, Balain DS, Badi AM, et al. (1994) Mitochondrial genetic variation in European, African and Indian cattle populations. Anim Genet 25: 265-271.

6. Rollinson DHL (1994) Bali Cattle. In: Mason IL, ed. Evolution of domestic animals. Essex: Longman.

7. McCool C (1992) Buffalo and Bali cattle-exploiting their reproductive behaviour and physiology. Trop Anim Health Prod 24: 165-172.

8. Felius M (1995) Cattle Breeds: An Encyclopedia Misset, Doetinchem, The Netherlands.

9. Kikkawa Y, Amano T, Suzuki H (1995) Analysis of genetic diversity of domestic cattle in east and Southeast Asia in terms of variations in restriction sites and sequences of mitochondrial DNA. Biochem Genet 33: 51-60.

10. Kikkawa Y, Takada T, Sutopo, Nomura K, Namikawa T, et al. (2003) Phylogenies using mtDNA and SRY provide evidence for male-mediated introgression in Asian domestic cattle. Anim Genet 34: 96-101.

11. Namikawa T (1981) Geographic distribution of bovine Hemoglobin-beta (Hbb) alleles and the phylogenetic analysis of the cattle in Eastern Asia. Zeitschrift fur Tierzuchtung and Zuchtungsbiologie 98: 151-159. the data: KM MO HTAVT SM BHV GA JAL. Contributed reagents/ materials/analysis tools: KM HRM BP RWP. Wrote the paper: KM GA HRM BC JAL.

12. Namikawa T, Widodo W (1978) Electrophoretic variation of hemoglobin and serum albumin in the Indonesian cattle including Bali cattle. Japanese Journal of Zootechnical Science 49: 817-827.

13. Nijman IJ, Otsen M, Verkaar EL, de Ruijter C, Hanekamp E, et al. (2003) Hybridization of banteng (Bos javanicus) and zebu (Bos indicus) revealed by mitochondrial DNA, satellite DNA, AFLP and microsatellites. Heredity 90: $10-16$.

14. Verkaar EL, Vervaecke H, Roden C, Romero Mendoza L, Barwegen MW, et al. (2003) Paternally inherited markers in bovine hybrid populations. Heredity 91: $565-569$.

15. Sambrook J, Fritsch EF, Maniatis T (1989) Molecular cloning. A Laboratory Manual Cold Spring Harbor Laboratory Press.

16. Verkaar ELC, Nijman IJ, Boutaga K, Lenstra JA (2002) Differentiation of cattle species in beef by PCR-RFLP of mitochondrial and satellite DNA Meat. Science 60: 365-369.

17. Nijman IJ, Van Boxtel DJ, Van Cann LM, Cuppen E, Lenstra JA (2008) Phylogeny of Y-chromosomes from interbreeding bovine species. Cladistics 24: $1-4$.

18. Ginja C, Telo da Gama L, Penedo MC (2008) Y Chromosome Haplotype Analysis in Portuguese Cattle Breeds Using SNPs and STRs. J Hered.

19. Gotherstrom A, Anderung G, Hellborg L, Elburg R, Smith C, et al. (2005) Cattle domestication in the Near East was followed by hybridization with aurochs bulls in Europe. Proc Biol Sci 272: 2345-2350.

20. Kumar P, Freeman AR, Loftus RT, Gaillard C, Fuller DQ, et al. (2003) Admixture analysis of South Asian cattle. Heredity 91: 43-50.

21. Bryant D, Moulton V (2004) Neighbor-net: an agglomerative method for the construction of phylogenetic networks. Mol Biol Evol 21: 255-265. 
22. Pritchard JK, Stephens M, Donnelly P (2000) Inference of population structure using multilocus genotype data. Genetics 155: 945-959.

23. Rosenberg N (2004) DISTRUCT: a program for the graphical display of population structure. Molecular Ecology Notes 4: 137-138.

24. Bradshaw CJ, Isagi Y, Kaneko S, Bowman DM, Brook BW (2006) Conservation value of non-native banteng in northern Australia. Conserv Biol 20: 1306-1311.

25. Freeman AR, Meghen CM, Machugh DE, Loftus RT, Achukwi MD, et al. (2004) Admixture and diversity in West African cattle populations. Mol Ecol 13: 3477-3487.

26. Barwegen M (2005) Gouden hoorns. De geschiedenis van de veehouderij op Java, 1850-2000. [Golden Horns. The history of livestock in Java, 1850-2000] Leiden.
27. Yu Y, Nie L, He ZQ, Wen JK, Jian CS, et al. (1999) Mitochondrial DNA variation in cattle of south China: origin and introgression. Anim Genet 30: 245-250.

28. Krediet G (1913) De rundveefokkerij op Java en Madoera [Cattle breeding on Java and Madura]. Batavia: Javasche Boekhandel \& Drukkerij.

29. 't Hoen H (1919) Veerassen en Veeteelt in Nederlandsch-Indië [Cattle breeds and husbandry in the Dutch Indies]. Batavia: G. Kolff \& Co.

30. Payne WJA, Rollinson DHL (1973) Bali Cattle. World Animal Reviews 7: $13-21$.

31. Payne WJA, Rollison DHL (1976) Madura Cattle. Zeitschrift fur Tierzuchtung and Zuchtungsbiologie 93: 89-100.

32. Rowlinson P, S M, Nefzaoui A, eds (2008) Livestock and Global Climate Change: Cambridge University Press. $216 \mathrm{p}$ 